УДК 376.091.21:005.336.2

DOI: http://dx.doi.org/10.30970/vpe.2018.33.9946

\title{
DIDACTIC STRATEGIES IN ACTIVITY OF TEACHING CHILDREN WITH SPECIAL EDUCATIONAL REQUIREMENTS
}

\section{Otiliia Dandara, Maia Shevchuk}

\author{
Moldova State University, \\ Alexei Mateevici Street, 60, Chisinau, Moldova, MD-2009
}

The article discloses didactic strategies in activity of teaching children with special educational requirements. Education strategies are characterized by flexibility, adapting themselves to specific situations and learning conditions. The pupil builds his/her own learning pathway, in relation to the individual potential and interactive context.

Learner-centered didactic strategy is namely an active and interactive one.

The approach of interactive teaching strategies falls within the general issue of developing the educational paradigm referring to the teaching-learning-evaluation dimension, highlighting the active and participative character of the learners and the possibility of efficient cooperation and communication.

The authors singled out the principles standing for building of interactive strategies (constructing of one's own meanings and interpretations of instruction contents; disputing and negotiations, not imposing of objectives; promoting teaching-learning-evaluating methodological alternatives; requiring transdisciplinary informations and multidimensional analyses of reality; a more reflexive evaluation than a criterial one, by means of alternative evaluation methods; promoting learning by discoveries and problem solving).

Definition of the concept interactive-creative learning is given as a process of creating significations as regards to new information and prior knowledge, of transforming cognitive structures of the pupil, as a result of incorporating new capacities and knowledge.

It is emphasized that an interactive person is that one who directly interrelates with others, one hand, or with the study material, on the other hand, by means of processes of transformative action and cognitive filters, of personalization of learning contents.

The authors used cooperative strategies, tutorial strategies and multisensorial assistance strategies prove to be the most efficient in dealing with children with special educational needs.

It is stated that for or a better success in using the strategy of learning through cooperation, the teacher must possess the following competences: energizing competence, empathic competence, ludic competence, organizational competence, interrelational competence.

The authors pay attention to the fact that in organizing the educational process with children with special needs, tutorial strategies are very valuable, and they can be realized in different means: peer tutoring; reverse role tutoring; cross-age tutoring.

It is proposed recommendations and guiding suggestions for selecting strategies for children with diverse special educational needs and examples from this are provided.

(C) Dandara O., Shevchuk M., 2018 
The specificity of group interactive strategies promote the interaction between the minds of the participants, their personalities, leading to more active learning and with obvious results.

It is infered positive aspects of teamwork in the class of students.

Key words: education, educational system, educational process, didactic strategies, competence.

Promoting inclusion and teaching from an inclusive perspective require a broad vision and specific skills that all teachers should possess, not just those who directly assist a child with special educational needs. Inclusive education and educational systems, in general, have evolved to the point where all teachers need to know that diversity tackles all groups of children at all levels of education, and that addressing different needs of the children is what fundamentally marks the new trends in education [4, p. 11].

Imposing itself as a new type of education, flexible and adaptable to the needs of all children, in general, and to those of the children with disabilities, in particular, inclusive education stands out from traditional education. The concept of inclusive strategy focuses on the inspired, original and creative application in a new way within any case of the traditional and preexisting methods and means, accepting their modification. In essence, inclusive education strategies are microgroup, active-participative, collaborative, partnership, implicit, organizational and socializing ones [3].

Indicating some guidelines of the optimal route to achieving goals, inclusive education strategies are characterized by flexibility, adapting themselves to specific situations and learning conditions. This adaptive restructuring largely depends on the creativity and spontaneity of the teacher, on their ability to identify the pupils' needs and to capitalize their strengths.

In designing and organizing the educational process, in general, and for children with special educational needs, in particular, the pupil-centered learning strategy - the individual knowledge building activity - is valuable. In other words, the pupil builds his/her own learning pathway, in relation to the individual potential and interactive context. Learner-centered didactic strategy is namely an active and interactive one.

The approach of interactive teaching strategies falls within the general issue of developing the educational paradigm referring to the teaching-learningevaluation dimension, highlighting the active and participative character of the learners and the possibility of efficient cooperation and communication.

The interactive didactic strategies, as group strategies, involve the collaborative work of pupils organized into microgroups or work teams to achieve the expected objectives (solutions to a problem, creation of alternatives). They are based on mutual support in research and learning, and individual participation is stimulated, training the subjects with all their personality (cognitive, affective, 
ISSN 2078-5526. Вісник Львівського університету. Серія педагогічна. 2018. Випуск 33

volitional, and social skills). They require effort to adapt to group rules, tolerance towards peers' opinions and views, developing the self-evaluation capacities. They are strategies of active interaction between the participants in the activity (pupilpupil, pupil-teacher) [4, p. 174-175].

Under the conditions of proper use, the cooperative strategies prove to be efficient in training children with special educational needs.

In this sense, C.L. Oprea states that interactive learning, which is being realized as opposed to others and to the study material, bases itself on constructive and deconstructive processes. It emerges as an outcome to individual and collective efforts by means of learner/teacher interraction, on one hand, and of learner/learning content on the other hand. Interractive learning targets social changes in gaining something new, thus stimulating redefining of senses, receptivity towards new experiences, seeking and exploring, analysis, synthesis, generalization, abstractization, stressing the connection between concepts, and requiring a profound intellectual implication.

From this point of view, the principles standing for building of interactive strategies are:

1. Constructing of one's own meanings and interpretations of instruction contents.

2. Disputing and negotiations, not imposing of objectives.

3. Promoting teaching-learning-evaluating methodological alternatives.

4. Requiring transdisciplinary informations and multidimensional analyses of reality.

5. A more reflexive evaluation than a criterial one, by means of alternative evaluation methods.

6. Promoting learning by discoveries and problem solving [5, p. 27].

Interactive-creative learning is a process of creating significations as regards to new information and prior knowledge, of transforming cognitive structures of the pupil, as a result of incorporating new capacities and knowledge.

Thus, we can state that an interactive person ist that one who directly interrelates with others, on one hand, or with the study material, on the other hand, by means of processes of transformative action and cognitive filters, of personalization of learning contents.

In this sense, didactic strategies are, first of all, of learning through collaboration and cooperation.

When used appropriately, cooperative strategies, tutorial strategies and multisensorial assistance strategies prove to be the most efficient in dealing with children with special educational needs.

Cooperative strategies are valuable because they facilitate not only learning, but also communication, socialization, and mutual knowledge among pupils, lead to reciprocal acceptance and integration in all aspects of pupils with special 
ISSN 2078-5526. Вісник Львівського університету. Серія педагогічна. 2018. Випуск 33

educational needs in the classroom. All students learn to actively listen, be tolerant, make decisions, and assume responsibilities within the group [2, p. 287]. When using these strategies, the modalities of grouping individuals to ensure the positive interdependence are important, maintaining the individual responsibility, resolving group conflicts, stimulating engagement and leading to an interactive learning process.

Interactive didactic strategies, which base themselves on learning by means of cooperation, provide children for the opportunity to specify the need of working together in a friendly environment. Group work offers them the possibility to test their ideas, revising opinions and developing interpersonal intelligence. Teamwork compensates for the drawbacks of individualized learning.

Collective activities have as foundation interdependent links among members of the group, who become generating sources for energies which are „favorable to intercommunication and cooperation in activities” [3, p. 205].

Cooperation ensures an open relationship between partners, it develops attitudes and behaviours based on trust, thus favouring development of positive attitudes towards learning and towards school. Teamwork has the same effects on the personality of pupils, the presence of interaction partners serving as intellectual stimulus. Learning by cooperation capitalizes intellectual exchange and ensures a learning logics which takes into account other people's opinions [5, p. 157].

Learning by cooperation requires practical and intellectual effort from the part of pupils and from the part of the teacher, who coordinates the activities. For a better success in using the strategy of learning through cooperation, the teacher must possess the following competences:

- Energizing competence: presupposes the capacity of the teacher to make pupils want to get involved in activities, to solve the problem. Pupils must be encouraged and stimulated in order not to stop at the first descovery they make, thus get them involved in alternative solution seeking;

- Empathic competence: presupposes the ability to work with pupils, the teacher managing to be in their places. In this way, the teacher will know better the disciples and will enable communication with them;

- Ludic competence: refers to the capacity of the teacher to respond to pupils' messages adn requests, favorizing the integration of ludic elements in the learning activity in order to make it more attractive and to support the intellectual effort of the pupils;

- Organizational competence: refers to the ability of the teacher to organize pupils in teams, to maintain the rules which learning by cooperation require. At the same time, the teacher is the one who can intervene in critical situation, ensuring activity flow. The teahcer is the one who maintains the link between participants intervention and the topic of discussion; 
- Interrelational competence: refers to the availability to communicate with the pupils, targeted at developing the required social abilities in order to be able to integrate in the team. Tolerance and opening towards new things, as well as encouraging the originality of pupils' answers will produce the same ressponse from the part of the students.

The roles of the teacher obtains new valences, thus overcoming the traditional optics by means of which he/she had only been an information supplier. In organizing learning by cooperation the teacher becomes a coparticipant, alongside the pupil. He is the one who acoompanies the pupil in the act of knowledge. The dimensions of the learning process thus, obtain, in case of teamwork strategies formative valences, encouraging individual and collective progress.

In organizing the educational process with children with special needs, tutorial strategies are very valuable, and they can be realized in different means:

- Peer tutoring;

- Reverse role tutoring;

- Cross-age tutoring.

Peer tutoring, the so called „child-to-child” tutoring can be realized inside the school, and outside it, refering the homework or extracurricular activities program. Tutoring is mostly realized in an informal manner, based on ssome friendships or sympathies. Children who will have the role of tutors must be discreetly selected amongst those who have proven along time to be available and open to peffering help to others.

When tutoring is reciprocal, by reversing roles, the strategy becomes versatile. This type of strategies influences attitude change, conceptions shift. From this point of view, a good selection and usage of reverse role strategy is useful in activities with pupils who come with miscopnceptions and pre-set beliefs, who live with the feeling of inferiority. As a result of employing this strategy, the pupil gains trust in his own forces and in his value, thus, it becomes also useful for children with special needs, who seek to seek for respect and value in every person [4, p. 289-290].

A relatively new work method (in a national context), in case of working with children with special needs in general education, is class partnership among teachers. In order for this type of partnership to become indeed an efficient working method, it is necessary for this to be realized in predetermined conditions:

- Carrying aut common activities will be preceeded by reciprocal class assistance;

- Partnership activities will be rigurously planned;

- Complementary activtities will be carried out;

- Partnership activities will be evaluated, with specific conclusions regarding their efficiency. 
ISSN 2078-5526. Вісник Львівського університету. Серія педагогічна. 2018. Випуск 33

A few possible scenarios for organizing class partnership would be the following:

- One teahcer is engaged in teaching, while another one oberves/helps;

- Parallel teaching: the same content is taught to two different groups of pupils;

- Alternative teaching: there are two heterogenous groups of pupils in the class; teaching is realized to each group specifically;

- Teaching in stages: distributing some dimensions of classwork content, of class management and didactic activity.

- Team teaching: both teachers teach and ensure class management and didactic activity.

Teachers, regardless of their level of implication, are free to act and select the most adequate technologies in order to respond to the special needs of children, and thus, ensure the development of their potential. In the process of school inclusion of children with special needs, the teacher will keep in mind that:

- Learning is more important than teaching;

- Pupils learn in schools, using internal and external resources, proposed by the teacher and other pupils;

- The process of learning is more important than short-term results;

- Learning is effective and efficient both for the pupil and for the teacher;

- Learning difficulties are normal and they can become grounds for perfecting school results;

- In order to respond to the needs of every pupil, individual strategies will be proposed;

- Educational partnership is a form of expressing efficient relationships in the educational process;

- The teaching process is supported by capitalizing external resources of learning with messages and direct/indirect experiences;

- Internal resources come from empathy, which is manifested between the teacher and the pupil.

In selecting didactic strategies while organizing learning activities with children with special educational needs it is also necessary to take into account the typology of specific educational requirements valid for them. G.Bulat and Rusu N., by means of their research, provide recommendations and suggestions for practical activities with children attesting different categories of special educational needs [2]. 
Table 1. Recommendations and guiding suggestions for selecting strategies for children with diverse special educational needs

\begin{tabular}{|c|c|}
\hline Categories of SEN & Examples of strategies \\
\hline $\begin{array}{l}\text { Intellectual } \\
\text { disabilities }\end{array}$ & $\begin{array}{l}\text { 1. Organization of class in centres of learning: } \\
\text { - creating work zones } \\
\text { - using intuitive materials } \\
\text { - alternating learning styles } \\
\text { - diversification of activities } \\
\text { 2. Organization of class by forms of work: } \\
\text { - group activities } \\
\text { - pair activities } \\
\text { - individual work } \\
\text { 3. Creating a positive emotional balance: } \\
\text { - creating and stimulating the feeling of security } \\
\text { - capitalization of pupil success } \\
\text { - development of motivation for learning } \\
\text { 4. Permanent encouragement }\end{array}$ \\
\hline Learning difficulties & $\begin{array}{l}\text { 1. Knowledge of foreign learning styles: } \\
\text { - observation } \\
\text { - conversation } \\
\text { - evaluation } \\
\text { 2. Knowledge of requirements: } \\
\text { - direct observation } \\
\text { - analysis of different evaluation reports } \\
\text { - diverse information: from parents, colleagues, friends. } \\
\text { 3. Strenghts evaluation: } \\
\text { - tests } \\
\text { - roleplay } \\
\text { - observation etc. } \\
\text { 4. Permanent collaboration with different subjects: } \\
\text { - psychologist } \\
\text { - doctor } \\
\text { - other teachers } \\
\text { - parents etc. } \\
\text { 5. Permanent encouragement etc. }\end{array}$ \\
\hline
\end{tabular}


Otiliia Dandara, Maia Shevchuk

ISSN 2078-5526. Вісник Львівського університету. Серія педагогічна. 2018. Випуск 33

\begin{tabular}{|c|c|}
\hline Dizabilități de vedere & $\begin{array}{l}\text { 1. Activities for supporting independence: } \\
\text { - acquaintance with main tracks inside and outside schools } \\
\text { - colleagues accompanying } \\
\text { 2. Inclusion in class team: } \\
\text { - extracurricular activites } \\
\text { - parent meetings } \\
\text { - separation of tasks etc. } \\
\text { 3. Writing with capital/ bigger letters on blackboards/flipcharts } \\
\text { 4. Use of Braille alphabet } \\
\text { 5. Adaptation of teaching strategies: } \\
\text { - increasing written letters size } \\
\text { - graphic presentation } \\
\text { - using larger images } \\
\text { - stressing/bolding of tables and figures } \\
\text { - using ITC etc. } \\
\text { 6. Permanent ecouragement etc. }\end{array}$ \\
\hline Dizabilități de auz & $\begin{array}{l}\text { 1. Organization of class in a semi-circle: } \\
\text { - simetric communication } \\
\text { - lip reading } \\
\text { 2. Application of intuitive methods: } \\
\text { - demonstration } \\
\text { - graphic presentation } \\
\text { - presentation of images for illustrating learning content } \\
\text { - using ICT etc. } \\
\text { 3. Clear and concise formulation of tasks } \\
\text { 4. Repeating of tasks } \\
\text { 5. Permanent ecouragement etc. }\end{array}$ \\
\hline Autism & $\begin{array}{l}\text { 1. Communication activities: } \\
\text { - conversations } \\
\text { - excursions } \\
\text { - reducing anxiety and consolidation of the feeling of comfort } \\
\text { 2. Relationship activities: } \\
\text { - teacher-pupil communication } \\
\text { - pupil-pupil communication } \\
\text { - outside school communication } \\
\text { 3. Task differentiation: } \\
\text { - quiet, repeated routine tasks } \\
\text { - consequence in task presentation } \\
\text { - imaginative thinking, spontaneity } \\
\text { 4. Permanent encouragement etc. }\end{array}$ \\
\hline
\end{tabular}

In any situation, however, "instructing someone in a discipline does not mean to keep them in mind such results, but to teach them to participate in the process that makes it possible to create knowledge" [8, p. 6]. Active and interactive teaching strategies are successful in fulfilling this constructivist approach to learning. Interactive relationships that are established within workgroups stimulate 
ISSN 2078-5526. Вісник Львівського університету. Серія педагогічна. 2018. Випуск 33

the participation of each member to find the optimal solution, to solve the tasks or the problem that has arisen.

The specificity of group interactive strategies and, implicitly, of methods and techniques lies in the fact that they promote the interaction between the minds of the participants, their personalities, leading to more active learning and with obvious results. This type of interactivity determines the learner's identification with the learning situation in which he/she is trained, thus becoming the master of his/her own transformations and training.

Interactivity requires both competition - defined as "a motivational form of self-assertion, including self-promotion, in which the individual rivals others to acquire a social status or superiority", as well as cooperation, which is a "socially oriented activity in within which the individual cooperates with others to achieve a common goal" [1, p. 39]. They are not antagonist; both involve a certain degree of interaction, as opposed to individual behavior.

Under the conditions of performing simple tasks, group activity is stimulating, generating contagious behavior and competitive endeavor; in solving complex tasks, in solving problems, in getting the right solution it is facilitated by issuing multiple and varied hypotheses. Interaction stimulates the effort and productivity of the individual and is important for self-discovery of their own capabilities and limits, for self-evaluation.

Thus, we infer the following positive aspects of teamwork in the class of students:

- Favored interrelations have positive effects in terms of cognitive and social development of personality;

- develops multiple intelligences;

- stimulates and develops complex cognitive capacities (divergent thinking, critical thinking, later thinking - the ability to look and explore things in another way, to relax thinking control);

- group work allows division of tasks and responsibilities into parties much easier to achieve;

- Problem solving time is often shorter when working in a group than when trying to find solutions on one's own;

- Group interactions, emulation, increase interest in a given theme or task, motivating students to learn, including pupils with special educational needs;

- Teamwork gives students the opportunity to share their opinions, experiences, ideas, personal work strategies, information;

- The phenomenon of emotional blocking of creativity is minimized;

- The group gives a sense of trust, security and mutual engagement of members, which leads to the disappearance of the fear of failure, forming the courage to take the risk. 
Conclusion. Therefore, the design of teaching strategies is a complex activity from the part of the teacher, which presupposes, first of all, the selection, organization/combining of the teaching methods in relation to the planned objectives/objectives, having in mind: the approach towards learning; forms of organizing the teaching-learning-evaluation process; teaching aids; the time required to apply the chosen didactic strategies. In the case of inclusive education strategies, the role of the teacher differs, so he becomes an animator, counselor, moderator, member of the team.

1. Ausubel D., Floyd R. Învăţarea în şcoală. (Learning in the school). Bucureşti: Editura Didactică şi Pedagogică, 1981.

2. Bulat G., Rusu N. Suport educaţional. Asistența copiilor cu cerințe educaționale speciale. Ghid metodic. (Educational support. Assistance to children with special educational needs. Methodological guide). Chişinău: Bons Offices, 2015.

3. Cerghit I. Sisteme de instruire alternative şi complementare. Structuri, stiluri şi strategii. (Alternative and Complementary Training Systems. Structures, Styles and Strategies). Bucureşti: Aramis, 2002.

4. Educație incluzivă. Unitate de curs. (Inclusive Education. Course Unit.) / Coord. Velişco N., Bulat G., Chişinău: Bons Offices, 2017.

5. Oprea C. L. Strategii didactice interactive. Bucureşti: Editura Didactică şi Pedagogică, 2006. 2000.

6. Ungureanu Dorel. Educația integrată şi şcoala incluzivă, Timişoara,

7. Raynal F., Rieunier A. Pedagogie: dictionnaire des concepts cles. Appretissages formation et psichologie cognitive (Integrated Education and Inclusive School). Paris: E.S.F., 1997.

8. Whitehead A. N. The Aims of Education. London: Ernest Benn Limited, 1962. 


\title{
ДИДАКТИЧНІ СТРАТЕГІЇ У НАВЧАННІ ДІТЕЙ $З$ ОСОБЛИВИМИ ОСВІТНІМИ ПОТРЕБАМИ
}

\author{
Отілія Дандара, Майя Шевчук \\ Державний університет Молдови, \\ вул. А. Матеєвіча, 60, Кишинів, Молдова, МD-2009
}

\begin{abstract}
Висвітлено дидактичні стратегії навчання дітей 3 особливими освітніми потребами. Стратегії освіти характеризуються гнучкістю, адаптуючись до конкретних ситуацій та умов навчання. Учень будує свій власний шлях навчання відповідно до індивідуального потенціалу та інтерактивного контексту. Дидактична стратегія, орієнтована на учня, є активною та інтерактивною.
\end{abstract}

Авторами виокремлено принципи побудови інтерактивних стратегій (конструювання власних сенсів та інтерпретацій змісту навчання; обговорення та діалоги без нав'язування цілей; підтримка методологічних альтернатив викладаннянавчання-оцінювання; вимога трансдисциплінарної інформації та багатовимірного аналізу реальності; більше рефлексивного ніж критичного оцінювання за допомогою альтернативних методів; сприяння навчанню за допомогою відкриттів і вирішення проблем).

Визначено поняття інтерактивно-творчого навчання як процесу творення значень щодо нової інформації та попередніх знань, перетворення когнітивних структур учня внаслідок залучення нових можливостей та знань. Зазначено, що інтерактивна людина безпосередньо взаємодіє 3 іншими, 3 одного боку, або 3 навчальним матеріалом, 3 іншого боку, за допомогою трансформативних дій та когнітивного аналізу, а також персоналізації навчального змісту.

Автори використовували кооперативні стратегії, стратегії наставництва (тьюторства) та мультисенсорної допомоги, що виявилися найефективнішими в роботі з дітьми з особливими освітніми потребами. Зазначено, що для успішного застосування стратегій навчання шляхом співпраці вчитель повинен володіти багатьма компетенціями: енергійністю, емпатичністю, організаційністю, ігровою майстерністю та здатністю до міжособистісних стосунків.

Автори звертають увагу на те, що в організації процесу навчання дітей 3 особливими потребами дуже цінними є стратегії наставництва (тьюторства), які можуть бути реалізовані різними засобами: тьюторство ровесників; зміна ролей у наставництві; тьюторство учнів різного віку.

Запропоновано рекомендації та пропозиції щодо вибору стратегій для роботи iз дітьми з різноманітними спеціальними освітніми потребами. Специфіка групових інтерактивних стратегій сприяє взаємодії учасників, що зумовлює більш активне навчання та очевидні результати.

Ключові слова: освіта, система освіти, освітній процес, дидактичні стратегії, компетенція. 